\title{
Sexual behavior of Pecari tajacu (Cetartiodactyla: Tayassuidae) during periovulatory and early gestation periods
}

\author{
Suleima do Socorro Bastos da Silva ${ }^{a}$, Yvonnick Le Pendu ${ }^{\mathrm{b}}$, Otavio Mitio Ohashi ${ }^{\mathrm{a}}$, \\ Eunice Oba $^{\mathrm{c}}$, Natália Inagaki de Albuquerque ${ }^{\mathrm{d}}$, Alexandre Rossetto Garcia ${ }^{\mathrm{e}}$, \\ Pedro Mayor ${ }^{\mathrm{f}}$, Diva Anelie de Araujo Guimarães ${ }^{\mathrm{a}, *}$ \\ a Universidade Federal do Pará, Instituto de Ciências Biológicas, Laboratório de Reprodução Animal, Belém, PA, Brazil \\ b Universidade Estadual de Santa Cruz, Departamento de Ciências Biológicas, Ilhéus, BA, Brazil

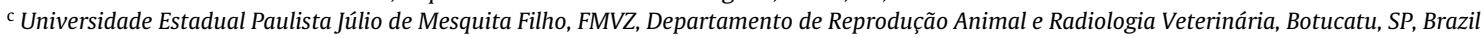 \\ d Empresa Brasileira de Pesquisa Agropecuária - Embrapa Amazônia Oriental, Belém, PA, Brazil \\ e Empresa Brasileira de Pesquisa Agropecuária - Embrapa Livestock Southeast, São Carlos, SP, Brazil \\ ${ }^{\mathrm{f}}$ Department of Animal Health and Anatomy, Universitat Autònoma de Barcelona, Edifici V, E-08193, Bellaterra, Barcelona, Spain
}

\section{A R T I C L E I N F O}

\section{Article history:}

Received 10 February 2016

Received in revised form 17 August 2016

Accepted 18 August 2016

Available online 20 August 2016

\section{Keywords:}

Behavior

Collared peccary

Estrus

Pregnancy

Reproduction

\begin{abstract}
A B S T R A C T
The goal of this study was to describe the sexual behavior in female and male collared peccary. Twenty females and twelve males were monitored in familiar and non-familiar units for two 60 days periods. During both phases, we recorded 2747 sexual interactions initiated by 20 different females toward males and 4461 sexual interactions initiated by 12 males toward females. The frequency of sexual interactions initiated per female significantly increased from proestrus to estrus, and they were significantly more frequently courted. Females initiated olfactory inspections 15.42 times more and were mounted 22.6 times more during estrus than during proestrus. Nulliparous and primiparous females copulated only when exposed to non-parental males. After estrus, the frequency of sexual interactions received by females sharply decreased. One mating event was recorded during the first gestation week and 31 mountings were observed after the second week. In conclusion, the behavioral monitoring is a useful procedure for the recognition of estrus. Our results suggest that ovulation may be associated with the end of the estrus, which will support future work in assisted reproduction in this species. To promote good handling practices, females of reproductive age should be removed from their family unit of origin.
\end{abstract}

(c) 2016 Elsevier B.V. All rights reserved.

\section{Introduction}

The collared peccary (Pecari tajacu) is one of the most hunted species in the Amazon (Bodmer and Robinson, 2004) and there is no conservation policy for this animal in Brazil (Desbiez et al., 2012). The reproductive performance of the collared peccary in captive conditions is satisfactory (Mayor et al., 2007b), with a better reproductive productivity compared to that of bovines (Nogueira and Nogueira-Filho, 2011).

In most tropical forests, subsistence hunting is a traditional practice among local communities for obtaining animal protein as

\footnotetext{
* Corresponding author.

E-mail addresses: suleima_silva@yahoo.com.br (S.d.S.B. da Silva), yvonnick@uesc.br (Y. Le Pendu), ohashi@ufpa.br (O.M. Ohashi), euniceoba@fmvz.unesp.br (E. Oba),natalia.albuquerque@embrapa.br (N.I. de Albuquerque), alexandre.garcia@embrapa.br (A.R. Garcia), pedrogines.mayor@uab.es (P. Mayor),diva@ufpa.br (D.A. de Araujo Guimarães).
}

well as increasing family income (Hoffman and Cawthorn, 2012; Nasi et al., 2011). Over-hunting, however, has led to a situation in which mammalian species in forested habitats are becoming locally or even widely extinct (Bodmer and Robinson, 2004), resulting in "the bushmeat crisis" (Milner-Gulland and Bennett, 2003). According to Hoffman and Cawthorn (2012), the inclusion of wild species in captive breeding programs may be a way of alleviating hunting pressures on these species, while allows for sustainable use of those resources, where there is considerable demand for wildlife products.

The female collared peccary is a non-seasonal polyestrous species with spontaneous ovulation (Mayor et al., 2004). This species shows a mean estrus cycle length of $28.4 \pm 5.45$ days, an average proestrus phase of $6.1 \pm 0.7$ days (range 6-9 days) (Guimarães et al., 2011), and estrus phase of $4.4 \pm 2.6$ days (range 2-6 days) (Mayor et al., 2007a). Mean gestation period is $138.6 \pm 4.8$ days (Mayor et al., 2012) and mean litter size is $1.85 \pm 0.43$ piglets per parturition (Mayor et al., 2007b). In captive 
Table 1

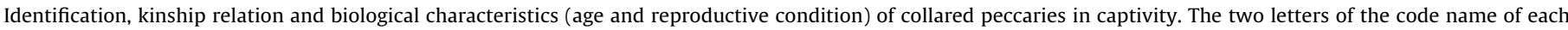
female indicates its reproductive condition: nulliparous (NU), primiparous (PR) or pluriparous (PL). Desc.: descendant of the parents in the group.

\begin{tabular}{|c|c|c|c|c|c|c|}
\hline Groups & Male & Age (years) & Kinship relation & Female & Age (years) & Kinship relation \\
\hline \multirow[t]{5}{*}{1} & M004 & 12 & Parent & PL107 & 10 & Parent \\
\hline & M030 & 8 & Desc. & NU103 ${ }^{a}$ & 4.5 & Desc. \\
\hline & & & & NU105 ${ }^{a}$ & 4 & Desc. \\
\hline & & & & NU108 & 4.5 & Desc. \\
\hline & & & & $\mathrm{NU} 347^{\mathrm{a}}$ & 0.7 & Desc. \\
\hline \multirow[t]{6}{*}{2} & M032 & 12 & Parent & PL111 & 5 & Parent \\
\hline & & & & PL113 & 5 & Parent \\
\hline & M284 & 3 & Desc. PL111 & NU104 & 3 & Desc. PL113 \\
\hline & M300 & 8 & Desc. PL113 & $\mathrm{NU} 110^{\mathrm{a}}$ & 3 & Desc. PL113 \\
\hline & & & & NU114 & 2 & Desc. PL113 \\
\hline & & & & NU115 & 3 & Desc. PL111 \\
\hline \multirow[t]{4}{*}{3} & M120 & 12 & Parent & PL119 & 8 & Desc. PL169b \\
\hline & M293 & 2 & Desc. PL169 & PR117 & 5 & Desc. PL169 \\
\hline & & & & $\mathrm{NU} 118^{\mathrm{a}}$ & 5 & Desc. PL169 \\
\hline & & & & $\mathrm{NU} 120^{\mathrm{a}}$ & 4 & Desc. PL169 ${ }^{b}$ \\
\hline \multirow[t]{5}{*}{4} & M121 & 12 & Parent & PL121 & 13 & Parent \\
\hline & & & & PL072 & 11 & Parent \\
\hline & M208 & 7 & Desc. PL121 & $\mathrm{NU} 122^{\mathrm{a}}$ & 3 & Desc. PL072 \\
\hline & M223 & 6 & Desc. PL072 & $\mathrm{NU} 124^{\mathrm{a}}$ & 4 & Desc. PL121 \\
\hline & & & & $\mathrm{NU} 125^{\mathrm{a}}$ & 3 & Desc. PL072 \\
\hline
\end{tabular}

a During the second phase, each group included only these females, and two non-parental adult males (M100 and M026).

b Parent female deceased of group 3.

conditions, the collared peccary female can become fertile during the early postpartum period (Mayor et al., 2006b).

Although knowledge of the reproductive biology of this species is of paramount importance to optimize the zootechnical performance of the captive collared peccary, behavioral aspects related to reproductive physiology are still poorly known and appropriate management practices have not yet been developed. This topic has been highlighted by two studies. Packard et al. (1991) stated that dominant males mounted more during estrus, and squabbles were frequent in this period. Even though, mounts also occurred when females were not fertile. Dutertre et al. (2001) observed that the rank order of mainly sexual and contact behaviors differs between males and females during estrus, but is similar when females are non-receptive. According to these authors, the contact behaviors were replaced by sexual behaviors in males during estrus, and markings of partner was the most frequent behavior in both sexes.

Characterizing the sexual behavior in the collared peccary may help to improve reproductive management practices and the implementation of assisted reproductive techniques, such as artificial insemination and embryo transfers. Optimizing the application of these biotechniques may support the removal of wildlife from the forest, since exchanging genetic materials will be possible among breeding centers. This study aims to describe the sexual behavior of female and male collared peccary, during the periovulatory and early gestation periods, in the presence or absence of their parents.

\section{Materials and methods}

\subsection{Animals}

The experiment was conducted in a scientific collared peccary breeding facility, located in Brazilian Agricultural Research Corporation $\left(01^{\circ} 24^{\prime} \mathrm{S} ; 48^{\circ} 20^{\prime} \mathrm{W}\right)$ in the city of Belém, state of Pará, Brazil. The experimental procedures were approved by the Ethical Committee for Animal Research from the Universidade Federal do Pará (Authorization number CEPAE-BIO 118-13), and were conducted in compliance with current Brazilian and international laws on the manipulation of animals for research purposes.

The study was conducted with 20 adult female collared peccaries ( 6 pluriparous, 13 nulliparous and 1 primiparous) and 12 males, aged between 8 months and 13 years (Table 1). All animals were adults, since puberty is achieved at seven months in females and at 12 months in males (Nogueira-Filho et al., 2004; Mayor et al., 2007b; Guimarães et al., 2013).

Each individual was marked with individually colored and numbered earring. The animals were kept in $36 \mathrm{~m}^{2}$ paddocks, under natural climatic conditions (Mayor et al., 2006c). Water was available ad libitum and food consisted of elephant grass (Pennisetum purpureum) and commercial ration for swine (2500 kcal and $14 \%$ crude protein/animal/day) (Albuquerque et al., 2010).

\subsection{Experimental design}

Two consecutive phases were established. During the first phase (familiar units), the sexual behavior of adults in their family group was observed, i.e. in the presence of their parents for a period of 60 days. During the second phase (non-familiar units), the sexual behavior of nulliparous and primiparous females was observed; these had been separated from their family group and kept in another paddock, with two non-parental adults males for 60 days. The aim of the second phase was to evaluate whether the removal of the parents could modify the sexual behavior of young adult females.

\subsubsection{Behavior monitoring}

Video recording sessions were conducted three times per week, from 6 a.m. to 9:30 a.m. and from 2 p.m. to 5:30 p.m., corresponding to the periods of greatest activity (Venturieri and Le Pendu, 2006). During a session, two groups were successively monitored during $75 \pm 24 \mathrm{~min}$. The behavioral interactions between collared peccaries were recorded through video footage of the groups, using an Xtreme Cam ATC3K (Oregon Scientific Brasil LTDA, São Paulo, Brazil), in order to optimize the detection of subtle behaviors and avoid animals' reactions to the presence of observers. A video footage of the entire enclosure was shot, providing a continuous recording of all occurrences (Altmann, 1974) of sexual behaviors. The shootage allowed identifying the interacting individuals.

An ethogram of the sexual behaviors (Table 2) was designed, based on Byers and Bekoff (1981), and unpublished previous research at the scientific collared peccary breeding facility. The 
Table 2

Ethogram of sexual behaviors observed (adapted from Byers and Bekoff, 1981).

\begin{tabular}{|c|c|}
\hline Behavior & Description of behavior \\
\hline Smelling & $\begin{array}{l}\text { Touching the rhinal disc successively to the } \\
\text { mate's body, except on the anogenital region. }\end{array}$ \\
\hline Muzzling & Moving the rhinal disc between the mate's fur. \\
\hline Olfactory inspection & $\begin{array}{l}\text { Smelling the female's anogenital region or the } \\
\text { male's scrotum region. }\end{array}$ \\
\hline Raising with snout & $\begin{array}{l}\text { The male places his snout between the female's } \\
\text { hind legs, while standing, and moves his head } \\
\text { vertically repeatedly, raising the female. }\end{array}$ \\
\hline Mounting & $\begin{array}{l}\text { The male climbs on the female's back resting } \\
\text { the abdomen and thorax on her rump. The } \\
\text { front legs hang and the hind legs remain on the } \\
\text { ground. }\end{array}$ \\
\hline Mating & $\begin{array}{l}\text { The male executes successive movements of } \\
\text { flexion and extension of the vertebral spine } \\
\text { while mounting the female. }\end{array}$ \\
\hline Biting & $\begin{array}{l}\text { The individual fastens or attempts to fasten its } \\
\text { teeth a mate's body part. }\end{array}$ \\
\hline Nibbling & $\begin{array}{l}\text { The individual lightly and successively } \\
\text { squeezes with his teeth some body part of an } \\
\text { opposite sex individual. }\end{array}$ \\
\hline Chin on partner & An individual places its chin on a mate. \\
\hline Estrous reflection & $\begin{array}{l}\text { The female moves her haunches to facilitate } \\
\text { the male's mounting, spreading her hind legs } \\
\text { and remaining immobile during the mount. }\end{array}$ \\
\hline Others & $\begin{array}{l}\text { Behaviors not previously described such as: } \\
\text { attack, mouth open defensively, head turning, } \\
\text { head licking, licking genitals. }\end{array}$ \\
\hline
\end{tabular}

video recordings were analyzed and each sexual interaction was transcribed on a digital spreadsheet based on: behavior, identities of the initiator and receiver, time of occurrence and duration of the interaction.

\subsubsection{Progesterone and colpocytological analysis}

Blood samples of $1 \mathrm{~mL}$ were collected, without sedation, every three days, into EDTA tubes by cephalic venipuncture for plasmatic progesterone (P4) determination. Plasma was removed after centrifugation at $1000 \times g$ for $15 \mathrm{~min}$, within $1 \mathrm{~h}$ of collection, and stored at $-15^{\circ} \mathrm{C}$ until assayed.

$\mathrm{P} 4$ concentrations were measured by a direct radioimmunoassay, quantified by the DPC Coat-A-Count Progesterone assay (Diagnostic Products Corporation, Los Angeles, USA). Plasma samples, with known high and low P4 concentrations, were pooled for assay validation. Intra and inter-assay variation coefficients were within internationally acceptable standards (10\%).The specificity of the assay for progesterone was 100\% (17-hydroxyprogesterone $0.3 \% ; 20 \alpha$-dihydroprogesterone: $2.0 \%$ ) and the sensitivity was $0.02 \mathrm{ng} / \mathrm{mL}$.

Analysis of vaginal cytology and the observation of clinical feature of the external genitalia were performed three times a week. Proestrus was defined as a period of up to nine days before estrus, where the exfoliative cytology arrangement initially showed high frequency of intermediate cells, and subsequently an increase of nucleated superficial cells. During the estrus phase, the vaginal smear on was characterized by an abrupt elevation of superficial cells to more than $66 \%$ of the total cells, and an absence of leukocytes. The external genitalia were reddish and tumescent only in this phase, and cervical fluid discharge was a little more intense (Guimarães et al., 2011). Aiming the minimum physical restraint of the animals, the time necessary for all procedure (blood collection and vaginal smears) was two minutes. During the first two months (first phase) the material was collected in all animals. After, two more months were necessary to this procedure, and only performed on the animals used during the second phase.

\subsubsection{Estrus phase and gestation diagnosis}

The following biological factors were considered to determine the estrus: 1- colpocytological analysis and clinical aspects of the vulva (Guimarães et al., 2011); 2- copulation (Mayor et al., 2007a); 3- low levels of progesterone $(1.0 \pm 0.5 \mathrm{ng} / \mathrm{mL}$ ) (Mayor et al., 2006b).

Pregnancy diagnosis was conducted by transabdominal ultrasonography approximately 75 days after a recorded mating, using portable equipment (Aloka SSD500, Japan) and $5.5 \mathrm{MHz}$ sectorarray transducer. Non-sedated females were scanned in lateral recumbency on either the left or right abdominal walls. Fetal viability was confirmed by the observation of a fetal heart beat (Mayor et al., 2005).

\subsection{Behavioral and statistical analysis}

We calculated the hourly frequency of sexual behaviors initiated and received by each female during phase 1 and 2 . Unilateral Wilcoxon matched-pairs signed-ranks tests were applied to test if the hourly frequency of sexual behaviors initiated and received by nulliparous and primiparous females increased significantly from the first to the second phase, and from proestrus to estrus during the second phase.

We applied a unilateral Wilcoxon matched-pairs signed-ranks test to verify if the frequency of sexual interactions initiated by adult males toward kin (i.e. sister, mother or daughter) was inferior to non-kin females during the first phase. Only adult males raised in a group with at least one kin and one non-kin adult female were considered for this analysis.

We calculated the mean hourly frequency of each sexual behavior that females initiated and received from males during the second phase when in proestrus and estrus. We applied unilateral Wilcoxon matched-pairs signed-ranks tests to verify if the frequencies of sexual behaviors increased from proestrus to estrus.

We compared the mean frequency of sexual interactions received by females and the mean $\mathrm{P} 4$ concentration from 7 days before to 13 days after estrus using Pearson's product moment correlation. Values were log-transformed to normalize the distribution of the residuals prior to the test. All statistical tests were done in the software program R (V. 3.2.2; R Core Team, 2015) and were considered significant at a threshold of $\mathrm{P}<0.05$.

\section{Results}

During both phases, we recorded 2747 sexual interactions initiated by 20 different females toward males and 4461 sexual interactions initiated by 12 males toward females. During the first phase, males initiated 659 sexual behaviors toward 15 females, of which 561 (85.1\%) were directed to two pluriparous females. The other four pluriparous females were already pregnant and rarely courted.

The nulliparous and primiparous females were rarely $(n=9)$ or not $(n=5)$ courted, receiving $0-10$ sexual behaviors. Nulliparous $(n=13)$, primiparous $(n=1)$ and pluriparous females $(n=6)$ initiated $0.02 \pm 0.03,0$ and $0.20 \pm 0.26$ sexual behaviors per hour and received $0.02 \pm 0.03,0.05$ and $0.85 \pm 1.08$ sexual behaviors per hour, respectively.

During phase 1 , seven adult males were raised with kin females and at least one non-kin female. They initiated 606 sexual behaviors toward non-kin females and 24 to kin females. Five of the seven males initiated more sexual behaviors towards non-parental females. Although the difference was not statistically significant $(n=7 ; V=6 ; P=0.10)$, because this five males initiated only two to fifteen sexual interactions during the whole phase. The two other males were responsible for most of the sexual behaviors toward 
Table 3

Hourly frequency of sexual interactions initiated and received by adult females of collared peccary, in proestrus and estrus during the second phase (non-familiar units). Mean values (Standard deviation).

\begin{tabular}{llllll}
\hline \multirow{2}{*}{ Behavior } & \multicolumn{2}{l}{ Initiated $(\mathrm{N} / \mathrm{h})$} & & \multicolumn{2}{l}{ Received $(\mathrm{N} / \mathrm{h})$} \\
\cline { 2 - 3 } \cline { 6 - 7 } & Proestrus & Estrus & & Proestrus & Estrus \\
\hline Biting & 0 & $0.01(0.04)$ & & - & - \\
Chin on mate & $0.26(0.18)$ & $0.54(0.54)$ & & $0.14(0.1)$ & $0.24(0.18)$ \\
Estrous reflection & $0.04(0.21)$ & $0.48(0.37)$ & & - & - \\
Licking genitals & - & - & & $0.01(0.04)$ & $0.01(0.04)$ \\
Mating & - & - & & - & $0.73(0.74)$ \\
Mounting & $0.07(0.11)$ & $0.14(0.18)$ & & $0.05(0.07)$ & $1.02(0.7)$ \\
Muzzling & $0.09(0.15)$ & $0.37(0.42)$ & & $0.11(0.1)$ & $0.37(0.31)$ \\
Nibbling & $0.73(0.63)$ & $1.99(0.76)$ & & $0.32(0.24)$ & $1.65(0.71)$ \\
Olfactory inspection & $0.01(0.01)$ & $0.11(0.15)$ & & $0.69(0.48)$ & $2.81(1.55)$ \\
Raising with snout & - & - & & - & $0.05(0.07)$ \\
Smelling & $0.41(0.25)$ & $1.19(0.67)$ & & $0.5(0.33)$ & $0.92(0.4)$ \\
Others & $0.16(0.08)$ & $0.3(0.31)$ & & $0.18(0.14)$ & $0.53(0.3)$ \\
\hline
\end{tabular}

non-kin females, and courted more one non-kin female than the other one. This preferential courtship resulted in sixteen mating events of these two pairs of animals. No mating event with other individuals was recorded during phase 1 .

During the second phase, all the primiparous and the thirteen nulliparous females female were courted and mated. The primiparous female initiated 0.82 and received 1.51 sexual behaviors per hour. The nulliparous females initiated $1.42 \pm 0.83$ and received $2.06 \pm 1.23$ sexual behaviors per hour. The nulliparous females initiated and received significantly more sexual behaviors during the second phase ( $\mathrm{n}=13 ; \mathrm{V}=0 ; \mathrm{P}<0.001$ for both tests).

Transabdominal ultrasonography confirmed that these fourteen females were all pregnant. The fertility rate of these females at $75.4 \pm 28.1$ gestation days was $100 \%$, with 22 fetuses observed during gestational ultrasonography.

Based on sexual behaviors and hormonal analysis, the length of the estrus phase was $5.3 \pm 1.6$ (4-8) days. The average level of plasmatic progesterone observed during this phase was $1.2 \pm 0.6 \mathrm{ng} / \mathrm{mL}$.

Nulliparous and primiparous females were filmed for $20.1 \pm 7.2 \mathrm{~h}$ during proestrus and $18.2 \pm 8.8 \mathrm{~h}$ during estrus. Females initiated significantly less sexual interactions per hour when in proestrus than in estrus (mean number of sexual interactions initiated per female in proestrus was $1.70 \pm 0.85$ behaviors/individual/hour, and in estrus was $4.77 \pm 2.26$ behaviors/individual/hour; $\mathrm{n}=10 ; \mathrm{V}=1 ; \mathrm{P}=0.002$ ). Females in proestrus also aroused less sexual interest of males (mean number of sexual interactions received per female in proestrus was $2.12 \pm 0.88$ behaviors/individual/hour, and in estrus was $8.62 \pm 6.38$ behaviors/individual/hour; $\mathrm{n}=10, \mathrm{~V}=10$; $\mathrm{P}<0.001$ ).

The frequency sexual behaviors initiated by females and received from male increased significantly from proestrus to estrus: (initiated, $\mathrm{n}=9, \mathrm{~V}=0 ; \mathrm{P}=0.005$; received: $\mathrm{n}=10 ; \mathrm{V}=0 ; \mathrm{P}=0.005$ ). Females initiated 1.98 (chin on partner) to 15.42 more (olfactory inspection) of the different sexual behaviors during estrus than during proestrus (Table 3 ). Females also received 1.72 (chin on partner) to 22.6 (mounting) more sexual interactions during estrus than proestrus. No mating event was recorded during proestrus.

Nulliparous and the primiparous female were involved in 168 matings during the second phase, of which 167 when in estrus. Mating events were less frequent during day $0-3$ of estrus $(n=24)$ than during the day $4-8(n=143)$, corresponding to $0.19 \pm 0.37$ and $0.93 \pm 2.17$ mating per female and per hour (Fig. 1). Each mating lasted an average of $10.4 \pm 12.3 \mathrm{~s}$.

After estrus, the frequency of sexual interactions received by females sharply decreased (Fig. 1). Thus, a female received $7.14 \pm 6.35$ sexual interactions per hour during estrus, but only $1.42 \pm 1.4$ until five days after estrus. However, one mating event was recorded during the first gestation week and 31 mountings were observed in eight females after the second week of gestation (15-45 days of pregnancy). The frequency of sexual interactions received by a female was negatively correlated with the mean P4 concentration (Pearson's correlation $\mathrm{r}=-0.76$; $\mathrm{P}<0.001$; Fig. 1 ).

\section{Discussion}

Understanding the sexual behavior of a species is fundamental to improving its reproductive management, the application of assisted reproductive techniques and the initiation of programs for genetic improvement. The results from this study bring new information about the sexual behavior of the collared peccary, during the periovulatory and the early pregnancy periods.

Most females mated several times during estrus, independent of their reproductive history. However, nulliparous females were frequently courted and mated only during the second phase with non-parental males. For collared peccaries raised in familiar groups in captivity, the lack of opportunities to mate with non-parental partners may render these animals tolerant to endogamy (Kokko and Ots, 2006). However, in the wild, females mate occasionally with male relatives (Cooper et al., 2011). Mechanisms of parental recognition are effective in the selection of sexual partners in swine, especially when animals live together from birth (Puppe, 1998; Stookey and Gonyou, 1998). The parental recognition mechanism observed in swine may also occur in collared peccaries. During the first phase, adult males initiated more sexual interactions toward non-parental females. Although, there were more related females present in family units. Sexual behaviors toward kin were rare and no mating with relatives was observed. Therefore, management of the collared peccary in captivity should consider that a mechanism of reproductive inhibition might occur between related members of a group. In order to increase reproductive efficiency in intensive farming systems, it is suggested that nulliparous females of reproductive age should be removed from their family unit of origin.

As expected, the frequency of sexual interactions received by females increased from proestrus to estrus. Physical contacts with males were more frequent through nibbling, mounting and mating. Olfactory inspection of the anogenital region was the most frequent sexual interaction received by females in estrus, as noted by Dutertre et al. (2001), suggesting that males identify the sexual receptivity of a female through olfaction. The elevation of estrogen levels induce the manifestation of clinical signs of estrus in females collared peccaries that attract males (Mayor et al., 2007a), possibly by the presence of pheromones, especially in the cervical mucus. However, more detailed investigations are necessary regarding these chemical signals which are also present in urine and secretions, such as those from the scent-marking gland observed in other Tayassuidae (Waterhouse et al., 2001). The recognition of the fertile period is a key-factor in assisted reproduction programs. According to the results, the increased frequency of olfactory inspection by male collared peccaries constitutes a good behavioral indicator to detect estrus in female.

The duration of estrus observed in this study is similar to those previously described for this specie (Barbella, 1993; Mauget et al., 1997; Sowls, 1997). The females were observed mating mainly during the second half of the estrus (day 4-8). This coincided with the sexual receptivity observed in the last third of the estrus of the collared peccary, based in the vaginal cytology, appearance of the vulva and serum estrogens levels (Mayor et al., 2007a).

Accordingly, the duration of estrus in swine may vary from 24 up to $96 \mathrm{~h}$, with ovulation occurring in the final third of the period, i.e. $10-85 \mathrm{~h}$ after the beginning of this phase (Soede and Kemp, 1997). Thus, ovulation of collared peccaries may be associated with the end of the estrus phase, similar to what occurs in swine. This 


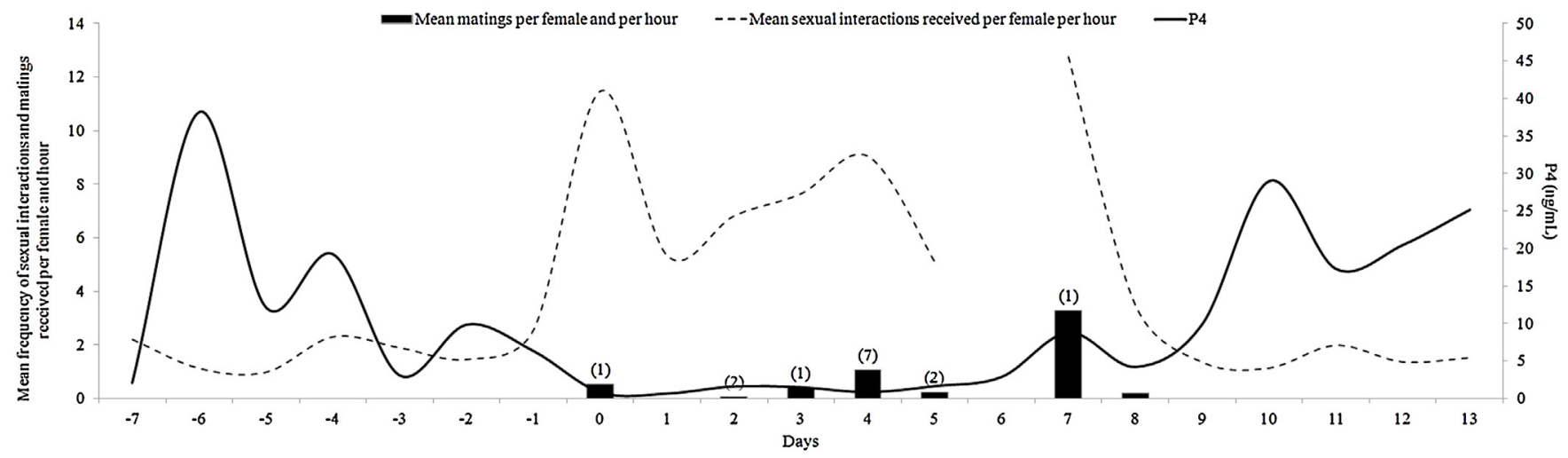

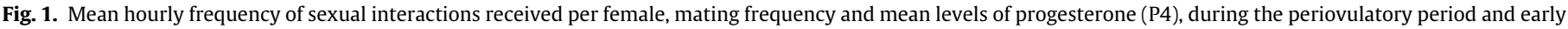
pregnancy in nulliparous and primiparous female of collared peccaries. Numbers in parentheses indicate the number of females that mated.

information is important to define reproductive management that seeks to establish the most fertile period for natural mating and artificial insemination in this species. In swine, mating lasts longer, with an average of five minutes, but this is infrequent (Hafez and Hafez, 2004), when compared to that observed in this study. For maximum reproductive performance in collared peccaries, based on females and males' sexual behavior, we recommend that natural or artificial mating occur in the final third of the estrus period.

The frequency of sexual interactions sharply decreased after estrus, but males eventually mounted females during their early pregnancy. Dutertre et al. (2001) did not observe mounting events when presenting a non-ovulating female to a male for $15 \mathrm{~min}$. Conversely, Packard et al. (1991), studying a group of collared peccaries raised in captivity, recorded more mountings of females in anoestrus than estrus, and also observed mounting of pregnant females. These authors concluded that mounting might be an artifact of captivity and not a good indicator of female receptivity.

The acceptance of mounting by the female soon after estrus may be related to the activity of the hypothalamic-pituitary-gonadal axis. The ovulation in collared peccary seems to be associated with the end of estrus, but ovulation could also occur after this phase, similar to that observed in cows (Jainudeen and Hafez, 2004). Further studies are required to better understand the intervals from the start or end of estrus to ovulation. However, at the beginning of gestation, the presence of the glycoprotein hormone, similar to the Equine Chorionic Gonadotropin-eCG, and placental estrogen may contribute to behavioral manifestations that lead to acceptance of mounting. According to Mayor et al. (2012), the increase of estradiol in pregnant collared peccaries occurs around the 15th day, during embryonic pre-implantation, increased until the delivery date, when it reached an average of $131.4 \pm 40.8 \mathrm{pg} / \mathrm{mL}$. Regular large antral ovarian follicles were also observed during gestation, suggesting continuous follicular growth during this phase (Mayor et al., 2006a).

\section{Conclusions}

This study is the first to link behavioral and physiological reproductive patterns during the periovulatory period and beginning of pregnancy in collared peccaries. Results indicate that behavioral monitoring is a useful procedure for the recognition of this period, as long as it is associated to the other morphophysiological parameters. The results presented in this study should be useful for good practices of handling of collared peccary in captivity and for the improvement of techniques of assisted reproduction.

\section{Acknowledgements}

Our thanks to Empresa Brasileira de Pesquisa Agropecuária and Laboratório de Endocrinologia FMVZ-UNESP-Botucatu, for the logistical support. To the Fundação Amazônia de Amparo a Estudos e Pesquisa do Pará for the doctorate scholarship. To veterinary doctor MSc. Priscila Reis Kahwage, academic Agatha Botelho and Mr. Deoclésio Chaves de Oliveira (in memoriam) for their help in collecting data. The authors thank Dr. Michele Singh, from the University of the West Indies, for assistance with the helpful comments.

\section{References}

Albuquerque, N.I., Guimarães, D.A., Tavares Dias, H.L., Le Pendu, Y., Reis Kahwage, P., Rossetto Garcia, A., 2010. Intensive production system of collared peccary (Pecari tajacu) in Brazilian Amazon. Adv. Anim. Biosci. 1, 480-481.

Altmann, J., 1974. Observational study of behavior-sampling methods. Behaviour 49, 227-266.

Barbella, S.L., 1993. Determination of the estrous cycle in the collared peccary (Tayassu tajacu). Rev. da Fac. Agron. 9, 167-174.

Bodmer, R.E., Robinson, J.G., 2004. Evaluating the sustainability of hunting in the neotropics. In: Silvius, K.M., Bodmer, R.E., Fragoso, J.M.V. (Eds.), People in Nature: Wildlife Conservation in South and Central America. Columbia University Press, New York, pp. 299-323.

Byers, J.A., Bekoff, M., 1981. Social, spacing, and cooperative behavior of the collared peccary, Tayassu tajacu. J. Mammal. 62, 767-785.

Cooper, J.D., Waser, P.M., Hellgren, E.C., Gabor, T.M., Dewoody, J.A., 2011. Is sexual monomorphism a predictor of polygynandry? Evidence from a social mammal, the collared peccary. Behav. Ecol. Sociobiol. 65, 775-785.

Desbiez, A.L.J., Keuroghlian, A., de Beisiegel, B.M., Medici, E.P., Gatti, A., Mendes Pontes, A.R., Campos, C.B., Tófoli, C.F., Moraes Junior, E.A., Azevedo, F.C., Pinho, G.M., Cordeiro, J.L.P., da Júnior, T.S.S., Morais, A.A., Mangini, P.R., Flesher, K., Rodrigues, L.F., Almeida, L.B., 2012. Avaliação do risco de extinção do cateto Pecari tajacu Linnaeus, 1758, no Brasil. Biodiversidade Bras. 3, 74-83.

Dutertre, C., Dubost, G., Feer, F., Henry, O., Mauget, R., 2001. Behaviours of collared and white-lipped peccaries in relation to sexual receptivity of the female. Acta Theriol. (Warsz.) 46, 305-318.

Hafez, B., Hafez, E.S.E., 2004. Comportamento reprodutivo. In: Hafez, B., Hafez, E.S.E. (Eds.), Reprodução Animal. Manole, São Paulo, pp. 293-306.

Hoffman, L., Cawthorn, D., 2012. What is the role and contribution of meat from wildlife in providing high quality protein for consumption? Anim. Front. 2, 40-53.

Jainudeen, M.R., Hafez, E.S.E., 2004. Bovinos e bubalinos. In: Hafez, B., Hafez, E.S.E. (Eds.), Reprodução Animal. Manole, São Paulo, pp. 159-171.

Kokko, H., Ots, I., 2006. When not to avoid inbreeding. Evolution (N. Y.) 60, 467-475.

Mauget, R., Feer, F., Henry, O., Dubost, G., 1997. Hormonal and behavioural monitoring of ovarian cycles in peccaries. Zeitschrift fur Saugetierkunde 62, 145-149.

Mayor, P.G., Jori, F., Lopez-Bejar, M., 2004. Anatomicohistological characteristics of the tubular genital organs of the female collared peccary (Tayassu tajacu) from Northeastern Amazon. Anat. Histol. Embryol. 33, 65-74.

Mayor, P.G., López-Gatius, F., López-Béjar, M., 2005. Integrating ultrasonography within the reproductive management of the collared peccary (Tayassu tajacu). Theriogenology 63, 1832-1843. 
Mayor, P.G., Fenech, M., Bodmer, R.E., Lopez-Bejar, M., 2006a. Ovarian features of the wild collared peccary (Tayassu tajacu) from the northeastern Peruvian Amazon. Gen. Comp. Endocrinol. 147, 268-275.

Mayor, P.G., Guimarães, D.A., Lopez-Gatius, F., Lopez-Bejar, M., 2006b. First postpartum estrus and pregnancy in the female collared peccary (Tayassu tajacu) from the amazon. Theriogenology 66, 2001-2007.

Mayor, P.G., Le Pendu, Y., Guimarães, D.A., Da Silva, V., Tavares, H.L., Tello, M. Pereira, W., Lopez-Béjar, M., Jori, F., 2006c. A health evaluation in a colony of captive collared peccaries (Tayassu tajacu) in the eastern Amazon. Res. Vet. Sci. $81,246-253$

Mayor, P.G., Galvez, H., Guimarães, D.A., Lopez-Gatius, F., Lopez-Bejar, M., 2007a. Serum estradiol-17beta, vaginal cytology and vulval appearance as predictors of estrus cyclicity in the female collared peccary (Tayassu tajacu) from the eastern Amazon region. Anim. Reprod. Sci. 97, 165-174.

Mayor, P.G., Guimarães, D.A., Le Pendu, Y., Da Silva, J.V., Jori, F., López-Béjar, M., 2007b. Reproductive performance of captive collared peccaries (Tayassu tajacu) in the eastern Amazon. Anim. Reprod. Sci. 102, 88-97.

Mayor, P.G., Guimarães, D.A., López-Béjar, M., 2012. Progesterone and estradiol-17 $\beta$ as a potential method for pregnancy diagnosis in the collared peccary (Pecari tajacu). Res. Vet. Sci. 93, 1413-1417.

Milner-Gulland, E.J., Bennett, E.L., 2003. Wild meat: the bigger picture. Trends Ecol. Evol. 18, 351-357.

Nasi, R., Taber, A., Van Vliet, N., 2011. Empty forests, empty stomachs?: Bushmeat and livelihoods in the Congo and Amazon Basins. Int. For. Rev. 13, 355-368.

Nogueira-Filho, S., Nogueira, S.S., da, C., 2004. Captive breeding programs as an alternative for wildlife conservation in Brazil. In: Silvius, K.M., Bodmer, R. Fragoso, J.M.V. (Eds.), People and Nature: Wildlife Conservation in South and Central America. Columbia University Press, New York, USA, pp. 171-190.
Packard, J.M., Babbitt, K.J., Franchek, K.M., Pierce, P.M., 1991. Sexual competition in captive collared peccaries (Tayassu tajacu). Appl. Anim. Behav. Sci. 29, 319-326. Puppe, B., 1998. Effects of familiarity and relatedness on agonistic pair relationships in newly mixed domestic pigs. Appl. Anim. Behav. Sci. 58 233-239.

R Core Team, 2015. R: A language and environment for statistical computing.

Soede, N.M., Kemp, B., 1997. Expression of oestrus and timing of ovulation in pigs. J. Reprod. Fertil. Suppl. 52, 91-103.

Sowls, L.K., 1997. Javelinas and Other Peccaries, Their Biology, Management and Use, 2nd ed. A\&M Universiy Press, Texas.

Stookey, J.M., Gonyou, H.W., 1998. Recognition in swine: recognition through familiarity or genetic relatedness? Appl. Anim. Behav. Sci. 55, 291-305.

Venturieri, B., Le Pendu, Y., 2006. Padrões de atividades de caititus (Tayassu tajacu) em cativeiro. Rev. Etol. 8, 35-43.

Waterhouse, J.S., Hudson, M., Pickett, J.A., Weldon, P.J., 2001. Volatile components in dorsal gland secretions of the white-lipped peccary, Tayassu pecari, from Bolivia. J. Chem. Ecol. 27, 2459-2469.

Nogueira, S.S., Nogueira-Filho, C.S., 2011. Wildlife farming: an alternative to unsustainable hunting and deforestation in Neotropical forests? Biodivers. Conserv. 20, 1385-1397.

Guimarães, D.A., Garcia, S.C.G., Le Pendu, Y., Albuquerque, N.I., 2011. Determinação do ciclo estral em catetos Pecari tajacu: aspectos colpocitológicos e clínicos. Acta Amaz. 41, 583-588.

Guimarães, D.A., Cardoso, D.L., Pantoja Ferreira, M.A., Albuquerque, N.I., 2013. Puberty in male collared peccary (Pecari tajacu) determined by quantitative analysis of spermatogenic cells. Acta Amaz. 43, 99-103. 